\title{
Characterization of Plant-Parasitic Nematode Communities Associated With Brinjal Crops in the Nagole Area of Rangareddy District, Hyderabad, Telangana, India (2011-2012)
}

\author{
B. Kavitha, Prof. V. Vanita Das
}

Department of zoology, Osmania University, Hyderabad, Telangana, India

\begin{abstract}
In Telangana, vegetable crops are now a very important component of the economy. However, their yield in farmer's fields is very low as a result of a recurring pest pressure, especially the plant-parasitic nematodes. This work aimed to identify nematodes parasites of brinjal crops of Nagole area of Rangareddy district, Hyderabad, Telangana State. Samples of soil and roots were taken in plant rhizosphere on the most important vegetable producing sites of the zone. Nematological analysis revealed 8 species of plantparasitic nematodes in the rhizosphere of the brinjal crops. In my study 8 nematode spp were identified Meloidogyne sp. Rotylenchulus sp. Pratylenchus sp. Helicotylenchus sp. Hoplolaimus sp. Heterodera sp. Trichodorus sp. Xiphinema sp. Brinjal or eggplant (Solanum melongena L.) is an important solanaceous crop of sub-tropics and tropics. The name brinjal is popular in Indian subcontinents and is derived from Arabic and Sanskrit whereas the name eggplant has been derived from the shape of the fruit of some varieties, which are white and resemble in shape to chicken eggs. It is also called aubergine (French word) in Europe. The brinjal is of much importance in the warm areas of Far East, being grown extensively in India, Bangladesh, Pakistan, China and the Philippines (Suman \& Dikshit, 2010).Eggplant (Solanum melongena L.), or Guinea squash, is in the 4th rank of vegetable crops (FAO, 1999). It is of considerably economic importance in Asia, Africa, and subtropics (India, Central America), but is also grown in some warm temperate regions (Mediterranean area, South of the USA) (Sihachakr et al., 1993). In 1999, 1.3 million ha were cultivated in the world for a total production of 21.2 million $t$, of which 92.4\% of the world production was covered by Asia (FAO, 1999). Although lower than that of tomato, eggplant nutritious value is comparable to other common vegetables (Gruber, 1977). Its fresh weight is composed of 92.7\% moisture, $1.4 \%$ protein, $1.3 \%$ fibre, $0.3 \%$ fat, $0.3 \%$ minerals, and the remaining $4 \%$ consists of various carbohydrates and vitamins $A$ and C (Khan, 1979).
\end{abstract}

Keywords: Brijal crop, plant parasitic nematodes, history

\section{Introduction}

Plant parasitic nematodes cause glob al losses of crop plants with an estimated loss of $\$ 125$ billion per year (Chitwood, 2003). In particular root-knot nematodes are very common in tropical and sub-tropical agriculture having wide host range and attacks more than 3000 plant species (Abad et al., 2003). So far 81 species of this destructive pest have been identified (Karssen, 2002). It has been reported to cause severe yield losses ranging between 17-20\% on egg plant (Sasser, 1979).Members of phytonematodes group have a stylet in their mouth and use it to penetrate the plant cells wall to absorb their contents. In addition to their direct effect on plant health, nematodes play different roles in disease complexes i.e vectors (e.g.several viruses), wounding agents, host structural and functional modifiers, host resistance breakers, and rhizosphere environmental modifiers as they cause increased root exudation, thereby affecting microbial communities and activity in the rhizosphere (Bardgett et al., 1999; brussard et al., 2001; Desaeger et al., 2004) Basing on plant age and the species one come across changes in nematode species and its rate of infection particularly seedlings more prone to damage by nematodes more because their tissues are highly susceptible to attack by nematode parasites as they are more favorable for nematode development (Ruehle, 1973). Plant parasitic nematodes are notorious pest in agricultural crops. These nematodes are taxonomically and tropically diverse in both terrestrial and aquatic habitats. They play an important role in terrestrial ecosystems through microbial grazing, root parasitism and affecting carbon and other nutrient cycles and their flow in soils (Yeats 2003). Finally it helps in the development of healthy and productive soil wich provides essential nutrients for plant growth. At the same time, it supports the diverse and active soil community that balances the total structure and function of an ecosystem (Insam, 2001; Friedel et al., 2001; Mader et al., 2002). Soil microorganism's especially some nematodes free living nematodes play important role in mineralization and break down of organic compounds in soil (Traunspurgeret al., 1997;Ajah et al 2006) Natural fallow improve the physicochemical parameters of soil that favour plant growth, its productivity (Brussard et al 2001).Cultivation of more crops per year, short duration of high yielding varieties, maximum use of fertilizers, increased frequency of irrigation, crop rotation, seasonal changes, soil moisture and temperature affects the nematode population structure (Rossner 1972; Yeates 1982; Norton and Niblack 1991).In India plant-parasitic nematode species like meliodogyne sp., pratyenchussp., have been reported to be widely distributed and causing considerable damage (Prasad et al, 1987). Root-knot nematodes Meloidogyne sp. are plantparasitic nematodes. Around 2000 plants are susceptible and Meloidogynespcause approximately $5 \%$ of crop loss at global level (Hussey and janssen, 2002).

Plant nematodes attack all crops grown in Florida, causing farmers millions of dollars in crop loss annually. Nematodes are generally cylindrical shape that attack 


\section{International Journal of Science and Research (IJSR) \\ ISSN (Online): 2319-7064}

Index Copernicus Value (2013): 6.14 | Impact Factor (2015): 6.391

mainly on roots of plants at the anterior region stylet is present which is hypodermal needle like structure with the help of stylet nematode penetrates into the root of plant. Mostly endo parasitic nematodes attack the root part of plant. In brinjal fields Soil and root samples are collected from rangareddy district.

\section{Methodology}

Soil and root samples were collected from brinjalfield crops. The fields are in Nagole and L.B Nagar, Rangareddy District. There are several methods for extraction of nematodes from soil and root sample.

\section{Direct method}

2. Bearmann Funnel method.

3. Cobb sieving method

The Plant parasitic nematodes are generally isolated from the soil surrounding roots on which they feed suspected soil sample root and foliar plant were collected from the plant. The collecting soil samples were $15-20 \mathrm{~cm}$ deep and the samples were with a portion of the root system and some of the distance foliage. After collecting the soil samples were carrying and stored in a polythin bag.
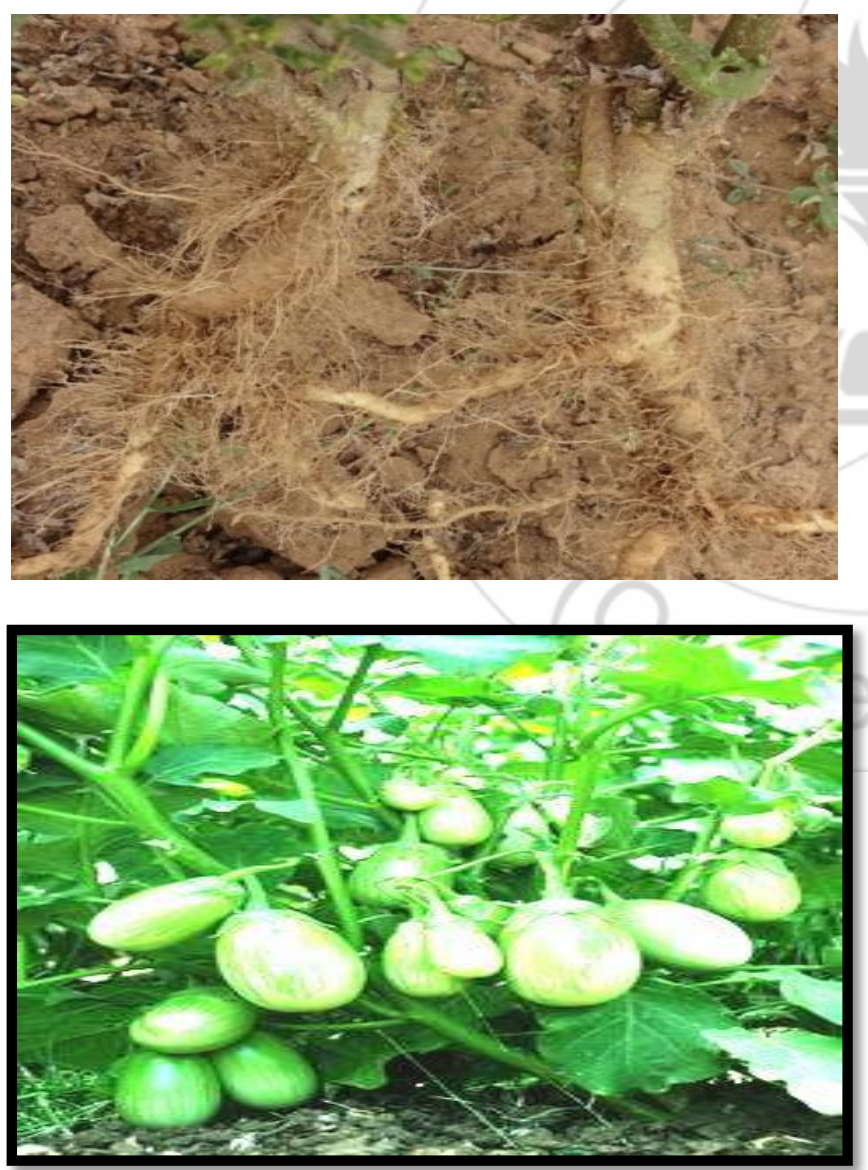

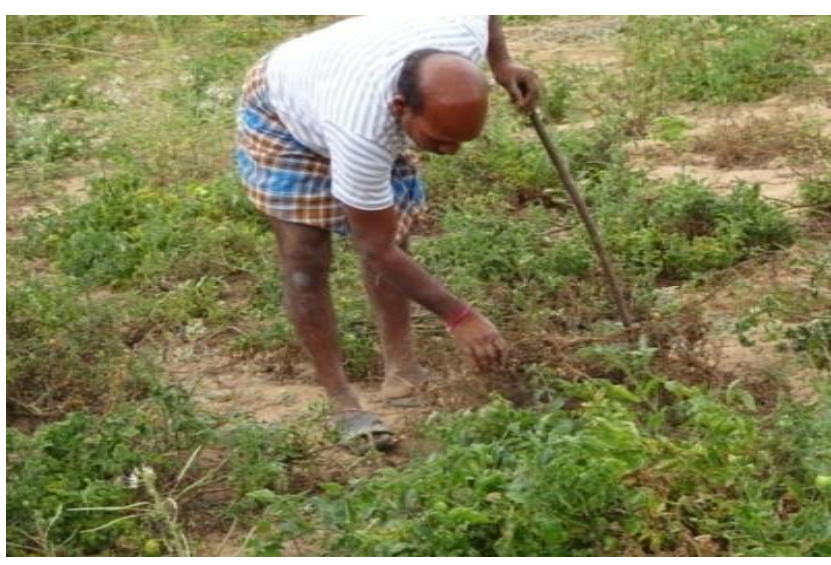

\section{Baermann Funnel Method}

The basic requirement for the Baermann funnel method is a funnel with a piece of rubber tube attached to a small glass tube and closed with a clip or clamp. The funnel is mounted on a support with a $5-\mathrm{cm}$ rubber tubing attached to the end of the funnel stem. A molstainless steel wire basket is placed in the funnel and a pinch clamp on the rubber tubing below the funnel stem. The funnel is filled nearly to the top with fresh tap water. The inside of the wire basket is covered with a double layer of tissue paper. The material for extraction (soil, small pieces of plant tissue, or organic material) is placed carefully on the tissue paper in the wire basket. Within $24 \mathrm{~h}$, active nematodes pass through the tissue paper and settle at the base of the funnel stem. A petri dish or vial is held below the end of the rubber tubing and the pinch clamp is opened to collect about $10 \mathrm{ml}$ of water containing nematodes. A major disadvantage of this method is poor oxygenation, particularly at the base of the glass tube where nematodes settle. The modified version of this method includes replacement of the funnel by a tray. A thin layer of soil is placed on a wire mesh in the tray containing water. This requires little labor and uses relatively simple equipment. The nematodes are recovered after $24-48 \mathrm{hr}$ depending upon ambient temperature $\left(25-30^{\circ} \mathrm{c}\right)$.

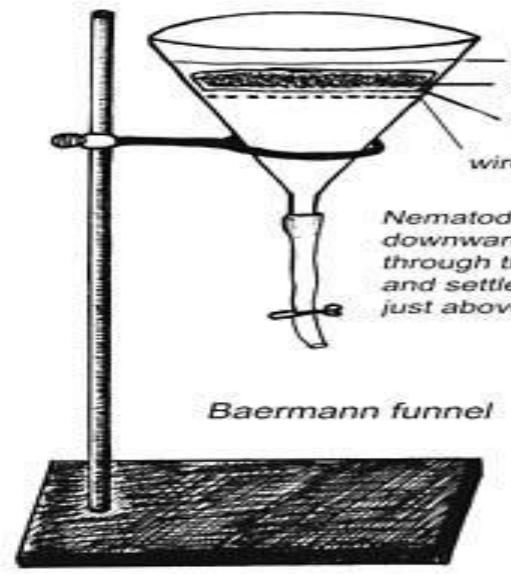




\section{Results and Discussion}

\section{Results:}

Table 1: Extraction and identification of different phytonematodes in brinjal crops of soil for the year 2011 to 2012

\begin{tabular}{|c|c|c|}
\hline Year & Phytonematode & Mean \pm SD \\
\hline \multirow{4}{*}{$\begin{array}{c}\text { Total year wise } \\
\mathbf{2 0 1 1}-\mathbf{2 0 1 2}\end{array}$} & Meloidogyne & $39.50 \pm 1.291$ \\
\cline { 2 - 3 } & Rotylenchulus & $33.25 \pm 1.708$ \\
\cline { 2 - 3 } & Helicotylenchus & $26.50 \pm 2.646$ \\
\cline { 2 - 3 } & Pratylenchus & $18.50 \pm 4.435$ \\
\cline { 2 - 3 } & Hoplolaimus & $20.00 \pm .816$ \\
\cline { 2 - 3 } & Heterodera & $15.50 \pm 2.082$ \\
\cline { 2 - 3 } & Xiphinema & $11.75 \pm 1.708$ \\
\hline
\end{tabular}

Table 2: Extraction and identification of different phytonematodes in brinjal crops of root for the year 2011 to 2014

\begin{tabular}{|c|c|c|}
\hline Year & Phytonematode & Mean \pm SD \\
\hline \multirow{4}{*}{$\begin{array}{c}\text { Total year wise } \\
\mathbf{2 0 1 1 - 2 0 1 2}\end{array}$} & Meloidogyne & $38.25 \pm 1.708$ \\
\cline { 2 - 3 } & Rotylenchulus & $31.25 \pm 1.258$ \\
\cline { 2 - 3 } & Helicotylenchus & $27.25 \pm 3.096$ \\
\cline { 2 - 3 } & Pratylenchus & $20.50 \pm 1.291$ \\
\cline { 2 - 3 } & Hoplolaimus & $18.25 \pm 1.708$ \\
\cline { 2 - 3 } & Heterodera & $15.00 \pm 1.826$ \\
\cline { 2 - 3 } & Xiphinema & $12.50 \pm 2.380$ \\
\hline
\end{tabular}

In my study nematode spp were identified Meloidogyne, Rotylenchulus, Helicotylenchus, Pratylenchus, Hoplolaimus, Heterodera and Xiphinema species were identified and these provided quantitative information on the frequencies and population densities of them.

In Table 1 in brinjal crops the soil sample for the year 2011-2012shown the average of Meloidogyne was $39.50 \pm 1.291$, Rotylenchulus was 33.25 \pm 1.708 , Helicotylenchu was 26.50 \pm 2.646 , Pratylenchuswas $18.50 \pm 4.435$, Hoplolaimuswas $20.00 \pm .816$, Heteroderawas $15.50 \pm 2.082$ Xiphinemawas $11.75 \pm 1.708$.

In Table.2.inbrinjal crops the root sample for the year 2011-2012; in 2011shown the average of the Meloidogynewas $38.25 \pm 1.708$ Rotylenchuluswas $31.25 \pm 1.258 \quad$ Helicotylenchuswas $\quad 27.25 \pm 3.096$ Pratylenchus was 20.50 \pm 1.291 Hoplolaimuswas $18.25 \pm 1.708$ Heteroderawas $15.00 \pm 1.826$ Xiphinemawas $12.50 \pm 2.380$.

\section{Discussion}

Feeding activities result in cellular necrosis which interferes with radial transport of water and solutes and leakage of stored photosynthetic products (Carneiro et al., 2002). Vascular feeders in vegetable crop studies included two species of root-knot nematode, $M$. incognita and $M$. javanica, which become sedentary endoparasites. This group of nematodes damages their hosts by redirecting large amounts of energy and nutrients from normal activities into development of the nematodes and their special feeding sites (Anwar, 1995; McClure, 1977)).

The altered tissues at feeding sites in vegetable crops also disrupt the vascular system by hampering the upward transport of water and dissolved nutrients by xylem and translocation of photosynthates to other regions of the plant by phloem (Hajera et al., 2009).
Roots severely galled by root-knot nematodes can predispose plants to root rots leading to a shorter life span of the crop. These galled tissues become succulent, poorly protected from invasion, and rich in nutrients. The result is a nutrient- rich food source which fungi can rapidly colonize (Abawi and Chen, 1998).). Root- knot nematode damage results in poor growth, decline in quality and yield of the crop and reduced resistance to other stresses like drought and disease. (Safdar A. 2012).

Meloidogyne incognita has often been reported as a damaging nematode pest of vegetable crops including recent work by these authors (Anwar and McKenry, 2010). A high level of root- knot nematode damage can lead to total crop loss. Nematode damaged roots do not utilize water or fertilizers as effectively, leading to additional losses for the grower (Trudgill and Phillips, 1997).

Crop losses due to plant parasitic nematodes are estimated to be about $12.3 \%$ in developed nations and $14.6 \%$ in the developing countries (Sasser and Feckman, 1987). However, these early estimates of nematode damage to vegetables appear underestimated when evaluating vegetable crops in third world countries. Data from the US indicate $4.5 \%$ damage for 28 vegetable crops (McSorley et al., 1987) but the estimates are $12 \%$ in India (Sehgal and Gaur, 1999).

The study on plant parasitic nematode in planted vegetables occurrence and density of plant parasitic nematodes associated with tunnel production of vegetables in the Punjab. Most nematodes identified in this survey can be anticipated to be a major threat to vegetable production and should be considered as serious pests (Anwar et al., 2007; Anwar and Mckenry, 2012). Initial pathogenicity tests should include, M. incognita, and M. Arenaria, P. penetrans and R. similis which taken alone can be of serious economic importance in the tropics and sub tropics (Anwar et al., 2007: Davide, 1988: Maqool et al., 1988). 


\section{International Journal of Science and Research (IJSR) \\ ISSN (Online): 2319-7064}

Index Copernicus Value (2013): 6.14 | Impact Factor (2015): 6.391

In vegetable soils Meloidogynesp are common in Worldwide where they parasitize vascular root tissues and induce their familiar root galls. Root knot nematode, $\mathrm{M}$. incognita, is among the most common (Anwar and Mckenry, 2010; Abawi and Widmer, 2000, David et al., 2003; Sasser, 1979; Barker and Olthof, 1976). In addition to extensive root galling leading to arrested root systems and its presence is often been associated with increased incidence and severity of Several field crops (Anwar and Mckenry, 2012), Depending on soil texture and prevailing weather conditions (Star, 1993).

Root lesion nematode, P.penetrans and the burrowing nematode, R.similis are migratory endoparasites of roots feedings among cortical tissues. Their infections can result in necrotic brown lesions and tunneling within rootlets. This can interfere with water and nutrient movement within plant tissues as well as increased leakage of harvested, stored food due to lesions (Dorhout et al., 1991).

Pratylenchuspenetrans is known to enhance the severity of verticillium wilt of vegetables (Vrain, 1987). Presence of these serious plant parasitic nematodes in abundance on vegetables produced within warmed tunnels should be taken seriously by growers. The association of these nematodes with vegetable crops has been reported to limit yields worldwide and there are now reports of yield losses from Punjab, Pakistan (Anwar and McKenry, 2012), India (Sehgal and Gaur, 1999), and USA (McSorleyet al., 1987).

The results of our study indicate that plant parasitic nematodes are widely distributed on vegetable crops cultivated in Nagole and L.B.Nagar. This information on nematode occurrence on vegetable crops will be helpful for growers for planning and administering nematode management strategies to reduce the nematode populations below their threshold levels. This study also demonstrated that the presences of many economically important plantparasitic nematodes are associated with Nagole and L.B. Nagar vegetable plants.

\section{Conclusion}

We extracted and identified the different phytonematodes in soil samples and root sample of brinjal crops of Nagole and LB Nagar region, Telangana.The nematodes identified were Meloidogynesp. Rotylenchulussp Pratylenchus sp. Helicotylenchus sp. Hoplolaimus sp. Heterodera sp. Trichodorus sp. Xiphinema sp. in the soil samples and root samples of brinjal crops. Meloidogynespp, Rotylenchulusspp, Pratylenchusspp, are significantly more in their number was calculated inbrinjal crop of soil samples and root sample as compared with other nematodes.

brinjal crops are economically important worldwide especially in India. The economic importance of the reported suspected nematode pest in tomato and brinjal crops with an aim of designing a proper nematode management strategy. This study provides important background information for planning and administering nematode management strategies in Nagole and LB Nagar region of Telangana.

\section{Acknowledgement}

Sincere thanks to ....

Guide Prof. V. Vanita Das, Department of Zoology, Osmania University, The financial assistance from the 06/UGC/12th Plan/Non-NET. My Farmers of Rangareddy District, Telangana, India, and my friends R. Shiresha, Sk. zareena, D. Nagesh, R. Murali, Md. Navaz, M. Anjaneyulu. M. Vijayalaksmi.

\section{References}

[1] Adeniji, M.O.E. Gichure, and J.Muigai.1979, Distribution and crop association study of plant parasitic nematodes in Kenya, Pp. 98.131 in C.N Karue and D.M. mukanya, eds. Second report of the university of Nairobi plant protection programme. Nairobi, Kenya..

[2] ANWAR.. S.A.AND VAN GUNDY. S.D. International of four nematodes on root shoot growth parameters ingrap.J. nematol., 21:276-283.

[3] ANWAR. S.A., 1989, Investigation on nematodes associated with field, vegetable and fruit crops, Technical Bulletin. Barani Agricultural College, Rawalpindi, Pakistan.

[4] Bafokuzara, N.1996 Incidence of different nematodes on vegetable and fruits crops and preliminary assessment of yield loss due to Meloidogyne species in Uganda. Nematologia Brasileira, 20 (1). Bafokuzara, N. (1983). Influence of six vegetable cultivars on reproduction of Meloidogynejavanica. Journal of nematology 15 (4): 559-564.

[5] BHATTI, D.S. and JAIN, R.K., 1977 Estimation of loss in okra, tomato, and Brinjal yield due to Meloidogynejavanica. Indian j. Nematol., 7: 37-41.

[6] Carneiro, R.M.D.G., Randing, o., Almeida, M.R. and Campos, A..D. (2000). Resistance of vegetable crops to meloidogynespp suggestion for crop rotation system. Nematologia Brasileira, 24(1):49-54.

[7] Courtney, W.D., Polley, D., and Miller, V.L. 1955. TAF, an improved fixative and nematode technique.

[8] Fassuliotis, G., and G.J. Rau. 1969. The relationship of Meloidogyne incognitaacrita to the incidence of cabbage yellows. Journal of nematology 1:219-222.

[9] Haougui A, Nouri mk, Basso A, Doumma A, Adam T. 2013 Plant parasitic nematode communities associated with pepper in Aguie region (Niger republic). Bot. Res int.6 (1): 01-06.

[10] Hough, A., and I.J Thomason. 1975. Effect of aldicarb on the behaviour of Heterobdera Schachtii and Meloidogynejavanica, Journal of nematology 7:221229.

[11]Hugot., J.P. Baujard; and Mcrand, S. (2001). biodiversity in helminthes and nematodes as a field study, An Overview nematology. 3, 199- 208

[12] Ikram, a. 1990.Beneficial soil microbes and crop productivity the planter $66: 640-648$

[13] Jatala, p. 1986. Biological control of plant parasitic nematodes, annual review of phytopathology 24:453489. 


\section{International Journal of Science and Research (IJSR) \\ ISSN (Online): 2319-7064}

Index Copernicus Value (2013): 6.14 | Impact Factor (2015): 6.391

[14] Kloepper, J.W., R. Rodriguez-kabana, J.A. Mcinory, and D.J.collins1991. Analysis of populations and physiological Characterization of microorganisims in rhizosphere of plants with antagonistic properties to phytopathogenic nematodes. Plant and soil.136:95102.

[15] OumarouAH. 2010. Characterization of parasitic nematodes communities associated with Solanaceae in the suburban area of Niamey.M. Sc thesis, University of Ougadougou, Burkina faso.

[16] Page, S.L.J1979.An assessment of the importance and control of plant parasiticnematodes of vegetable crops in Bangladesh.Pp.36 in O.D.M. Report of visit to Bangladesh Ascot, Berks, UK. Ministry of Overseas development.

[17]Pernilla E. j ohannes WA, Wim VDPH. 2004 Endoparasitic nematodes reduce multiplication of ectoparasitic nematodes, but do not prevent growth reduction of Ammophilaarenaria (L.) Link (marram grass). Appl.soil Ecol. 27:65-75.

[18] Seinhorstjw. 1962. Modifications of the elutriation method for extracting nematodes from soil. Nematologica 8; 117-128.

[19] Scinhorst, J.W. 1962 on the killing of nematodes 